\title{
IN VITRO ANTIOXIDANT AND ANTIHYPERGLYCEMIC ACTIVITIES OF HYDROETHANOLIC LEAF EXTRACT OF ACACIA CATECHU (L.F) WILLD
}

\author{
RAMESH B*, JAYABHARATHI V
}

Department of Biochemistry, PSG College of Arts \& Science, Coimbatore, Tamil Nadu, India. Email: bramesh2575@gmail.com

Received: 29 May 2017, Revised and Accepted: 24 July 2017

\section{ABSTRACT}

Objective: The aim of this study was to analyze the antioxidant and antihyperglycemic activities of hydroethanolic leaf extract of Acacia catechu (L.f) Willd.

Methods: The A. catechu (L.f) Willd. leaf extract was subjected to antioxidant activities such as 1,1-diphenyl-1-picryl hydrazyl (DPPH), hydroxyl radical $\left(\mathrm{OH}^{-}\right)$, nitric oxide radical $\left(\mathrm{NO}^{-}\right)$, and superoxide radical (SO) scavenging assays. Further, the leaf extract was subjected to antihyperglycemic activity by $\alpha$-amylase inhibition assay.

Results: The free radical scavenging activity of the plant extract was found to increase with increase in concentration (20-100 $\mu \mathrm{g} / \mathrm{ml})$ and the maximum activity was obtained at $100 \mu \mathrm{g} / \mathrm{ml}$, which was compared with the standard ascorbic acid. The percentage inhibition of free radicals was found to be $62.94 \pm 0.91 \%, 63.53 \pm 1.08 \%, 71.04 \pm 0.48 \%$, and $51.50 \pm 0.86 \%$ for $\mathrm{DPPH}, \mathrm{OH}^{-}, \mathrm{NO}^{-}$, and $\mathrm{SO}^{-}$, respectively. The $\mathrm{IC}_{50}$ for $\mathrm{DPPH}^{-} \mathrm{OH}^{-}, \mathrm{NO}^{-}$, and SO were recorded as $73.81 \pm 0.95,69.03 \pm 0.58,60.74 \pm 0.37$, and $83.10 \pm 1.00 \mu \mathrm{g} / \mathrm{ml}$. The $\mathrm{IC}_{50}$ value of $\alpha$-amylase inhibitory activity was found to be $71.17 \mu \mathrm{g} / \mathrm{ml}$.

Conclusion: The present investigations suggest that the A. catechu (L.f) Willd may serve as a potential source of natural antioxidant and antihyperglycemic agent that could have great importance in pharmaceutical preparations.

Keywords: Acacia catechu (L.f) Willd, 1,1-diphenyl-1-picryl hydrazyl, Hydroxyl radical, Nitric oxide radical, Superoxide oxide radical, $\alpha$-amylase inhibition.

(C) 2017 The Authors. Published by Innovare Academic Sciences Pvt Ltd. This is an open access article under the CC BY license (http://creativecommons. org/licenses/by/4. 0/) DOI: http://dx.doi.org/10.22159/ajpcr.2017.v10i11.20299

\section{INTRODUCTION}

Free radicals are highly reactive and oxygen-containing molecules. Various types of reactive oxygen species include hydroxyl radical $\left(\mathrm{OH}^{-}\right)$, superoxide anion radical, singlet oxygen, nitric oxide radical $\left(\mathrm{NO}^{-}\right)$, hypochlorite radical, and hydrogen peroxides [1]. Free radicals are produced by physiological/biochemical reactions or by pollution and other endogenous sources. Free radicals react with membrane lipids, proteins, nucleic acids, enzymes, and other small molecules, resulting in cellular damage [2]. The human system is protected by antioxidants, which play an important role in scavenging free radicals, and providing protection against degenerative diseases [3]. In recent years, the research is focused on natural antioxidants from medicinal plants to know their constituents and biological activity [4]. Plants are the rich source of alkaloids, phenolic acids, tannins, flavonoids, terpenoids, and other metabolites that act as primary antioxidants or free radical scavengers [5]. The imbalance between the production of reactive oxygen species and antioxidant defenses leads to oxidative stress [6]. Redox stress cause immune cells to release proinflammatory cytokines, reactive oxygen, and nitrogen species, that damages biological molecules and induce imbalances in physiological and pathological pathways [7]. $\alpha$-amylase is involved in the breakdown of long chain carbohydrates, serve as the major digestive enzyme and help in intestinal absorption. $\alpha$-amylase inhibitors are the potential targets for the development of lead compounds for the treatment of diabetes [8].

Acacia catechu (L.f) Willd is a moderate-sized tree, which belongs to the family of Leguminosae. It is commonly used in herbal preparations for diabetes [9]. Conventionally, A. catechu has been used as an antioxidant, anti-inflammatory, antimicrobial as well as antifungal property and also to treat diabetes and obesity [10]. Natural $\alpha$-amylase inhibitors from the dietary plants can be used as an effective therapy for treating post-prandial hyperglycemia with minimal side effects. The present study was carried out to investigate the antioxidant activity and inhibitory potential of $A$. catechu (L.f) Willd leaf extract on $\alpha$-amylase, in vitro. Hence, an attempt was made to find remedy for a prevalent clinical ailment through natural source.

\section{METHODS}

\section{Plant collection and preparation of extract}

The plant A. catechu (L.f) Willd was collected from Kanjikode, Kerala, identified and certified by a taxonomist at Botanical Survey of India (BSI), Tamil Nadu Agricultural University, Coimbatore, (Plant Identification No. BSI/SRC/5/23/2014-2015/Tech/699). The leaves of A. catechu (L.f) Willd were shade dried and ground to a coarse powder by a mechanical device. The extract was prepared using different solvents, namely, petroleum ether, chloroform, acetone, ethanol, hydroethanol, and water by cold maceration process. The filtrate was used for preliminary phytochemical analysis. Further studies were carried out using the $50 \%$ hydroethanolic extract, prepared using soxhlet apparatus. The extract was condensed to dryness using rotary evaporator and the crude residue obtained $(15 \% \mathrm{w} / \mathrm{w})$ was stored in an airtight container until use.

\section{Free radical scavenging assays}

1,1-diphenyl-1-picryl hydrazyl (DPPH) radical scavenging assay DPPH radical scavenging activity was assayed using the method of Brand-Williams et al. [11]. The radical scavenging activity of sample against DPPH was determined spectrophotometrically. The reaction mixture in a total volume of $3.0 \mathrm{ml}$ contained $1.0 \mathrm{ml}$ of DPPH, $0.5 \mathrm{ml}$ of sample and made up to $3.0 \mathrm{ml}$ with water. The tubes were incubated for 10 minutes at $37^{\circ} \mathrm{C}$. A blue chromophore was formed, the absorbance of which was measured at $515 \mathrm{~nm}$. 


\section{$\mathrm{OH}^{-}$scavenging assay}

$\mathrm{OH}^{-}$scavenging assay was measured by the method of Halliwell et al. [12]. The incubation mixture in a total volume of $1.0 \mathrm{ml}$ contained $0.1 \mathrm{ml}$ of buffer, $0.5 \mathrm{ml}$ of sample, $0.2 \mathrm{ml}$ of ferric chloride, $0.1 \mathrm{ml}$ of ascorbic acid, $0.1 \mathrm{ml}$ of ethylenediaminetetraacetic acid (EDTA), $0.1 \mathrm{ml}$ of hydrogen peroxide, and $0.2 \mathrm{ml}$ of 2-deoxyribose. The contents were mixed thoroughly and incubated at room temperature for 60 minutes, and then, added $1.0 \mathrm{ml}$ of thiobarbituric acid and $1.0 \mathrm{ml}$ of trichloroacetic acid. All the tubes were kept in a boiling water bath for 30 minutes. The absorbance of the supernatant was read in a spectrophotometer at $535 \mathrm{~nm}$ with reagent blank containing water in place of the extract.

\section{$\mathrm{NO}^{-}$scavenging assay}

$\mathrm{NO}^{-}$scavenging activity was measured by the method of Sreejayan and Rao [13]. The reaction mixture $(3.0 \mathrm{ml})$ containing $2.0 \mathrm{ml}$ of sodium nitroprusside $(10 \mathrm{mM}), 0.5 \mathrm{ml}$ of phosphate buffer saline $(1.0 \mathrm{M})$, and $0.5 \mathrm{ml}$ of different concentrations $(20-100 \mu \mathrm{g} / \mathrm{ml})$ of plant extract was incubated at $25^{\circ} \mathrm{C}$ for 150 minutes. After incubation, $0.5 \mathrm{ml}$ of the Griess reagent was added. Control experiments without the test compound, but with an equal volume of buffer were added. The absorbance of the chromophore formed during diazotization coupling with naphthyl ethylenediamine was read at $540 \mathrm{~nm}$.

\section{Superoxide radical (SO) scavenging assay}

The SO scavenging activity was studied using the method of Winterbourn et al. [14]. The assay mixture contained $(0.2-1.0 \mathrm{ml})$ sample with $0.1 \mathrm{ml}$ of Nitroblue tetrazolium ( $1.5 \mathrm{mM} \mathrm{NBT}$ ) solution, $0.2 \mathrm{ml}$ of EDTA ( $0.1 \mathrm{mM}$ EDTA), $0.5 \mathrm{ml}$ riboflavin $(0.12 \mathrm{mM})$, and $2.55 \mathrm{ml}$ of phosphate buffer $(0.67 \mathrm{M})$. The control tubes were also setup, wherein dimethyl sulfoxide was added instead of the sample. The reaction mixture was illuminated for 30 minutes and the absorbance at $560 \mathrm{~nm}$ was measured against the control sample. All the tests were performed in triplicate and the results averaged. The percentage inhibition was calculated by comparing the results of control and test samples using the formula:

$$
\begin{gathered}
\text { Absorbance }(\text { control })- \\
\text { Percentage inhibition }=\frac{\text { Absorbance }(\text { sample })}{\text { Absorbance }(\text { control })} \times 100
\end{gathered}
$$

\section{$\alpha$-amylase inhibition assay}

$\alpha$-amylase inhibition was studied using the method of Narkhede et al. [15]. The enzyme solution was prepared by dissolving $\alpha$-amylase in $20 \mathrm{mM}$ phosphate buffer $(\mathrm{pH}=6.9)$ at the concentration of $0.5 \mathrm{mg} / \mathrm{ml} .1 .0 \mathrm{ml}$ of the extract at various concentrations $(20,40,60$, 80 , and $100 \mu \mathrm{g} / \mathrm{ml}$ ) and $1.0 \mathrm{ml}$ of enzyme solution were mixed together and incubated at $25^{\circ} \mathrm{C}$ for 10 minutes. After incubation, $1.0 \mathrm{ml}$ of starch $(0.5 \%)$ solution was added to the mixture and further incubated at $25^{\circ} \mathrm{C}$ for 10 minutes. The reaction was then stopped by adding $2.0 \mathrm{ml}$ of dinitrosalicylic acid (DNS, color reagent), heated the reaction mixture in a boiling water bath for 5 minutes. After cooling, the absorbance was measured colorimetrically at $565 \mathrm{~nm}$. The inhibition percentage was calculated using the formula:

$$
\begin{gathered}
\text { Absorbance }(\text { control })- \\
\text { Percentage inhibition }=\frac{\text { Absorbance }(\text { sample })}{\text { Absorbance }(\text { control })} \times 100
\end{gathered}
$$

Statistical analysis

Data were expressed as mean \pm standard deviation.

\section{RESULT AND DISCUSSION}

\section{DPPH radical scavenging assay}

DPPH radical is used to investigate the antioxidant potential of a given compound in vitro. The hydroethanolic leaf extract of A. catechu (L.f)
Willd at 5 different concentrations $(20-100 \mu \mathrm{g} / \mathrm{ml})$, produced dosedependent radical scavenging activities. The plant extract showed the maximum scavenging effect on DPPH as $62.94 \pm 0.91 \%$ inhibition at $100 \mu \mathrm{g} / \mathrm{ml}$ whereas ascorbic acid showed $89.42 \pm 0.82 \%$ inhibition as shown in the Fig. 1 . The $\mathrm{IC}_{50}$ value of DPPH radical scavenging activity was found to be $73.81 \pm 0.95 \mu \mathrm{g} / \mathrm{ml}$. The radical scavenging activity indicates the antioxidant capacity of extract and its reducing properties might be associated with the presence of reductones [16]. In a similar study, Sanjay et al., reported that the methanolic heartwood extract of A. catechu showed promising DPPH radical scavenging activity. Since the $A$. catechu extract showed DPPH radical scavenging activity, the natural antioxidants present in the extract might possess the ability to neutralize free radicals and thereby act as scavengers, helping prevent cell and tissue damage.

\section{$\mathrm{OH}^{-}$scavenging assay}

$\mathrm{OH}^{-}$are the most reactive oxygen species that can cause oxidative damage to DNA, lipids, and proteins $[17,18]$. Scavenging of $\mathrm{OH}^{-}$is an important antioxidant activity because of very high reactivity of the $\mathrm{OH}^{-}$, enabling it to react with a wide range of molecules in the living cells, such as amino acids, sugars, lipids, and nucleotides [19]. The maximum scavenging effect for $\mathrm{OH}^{-}$was obtained at $63.53 \pm 1.08 \%$ inhibition at $100 \mu \mathrm{g} / \mathrm{ml}$ of the plant extract, whereas the standard ascorbic acid showed $78.14 \pm 0.75 \%$ inhibition as shown in the Fig. 2 . The $\mathrm{IC}_{50}$ value of $\mathrm{OH}^{-}$was found to be $69.03 \pm 0.58 \mu \mathrm{g} / \mathrm{ml}$. The scavenging activity may be due to the presence of flavonoids in the extract. As the hydroethanolic extract of A. catechu (L.f) Willd exhibit $\mathrm{OH}^{-}$activity, it can be assumed that this plant can be used as a marker for oxidative stress in cells and tissues.

\section{$\mathrm{NO}^{-}$scavenging assay}

$\mathrm{NO}^{-}$causes DNA fragmentation, cell damage, neurotoxicity, and lipid peroxidation [20]. The maximum scavenging effect of nitric oxide was

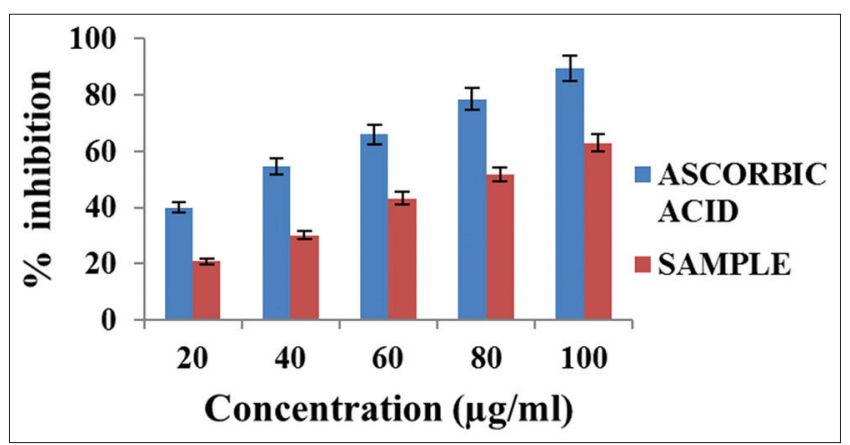

Fig. 1: 1,1-diphenyl-1-picryl hydrazyl radical scavenging assay of Acacia catechu (L.f) Willd. leaf extract. Values are represented in mean \pm standard deviation of triplicates

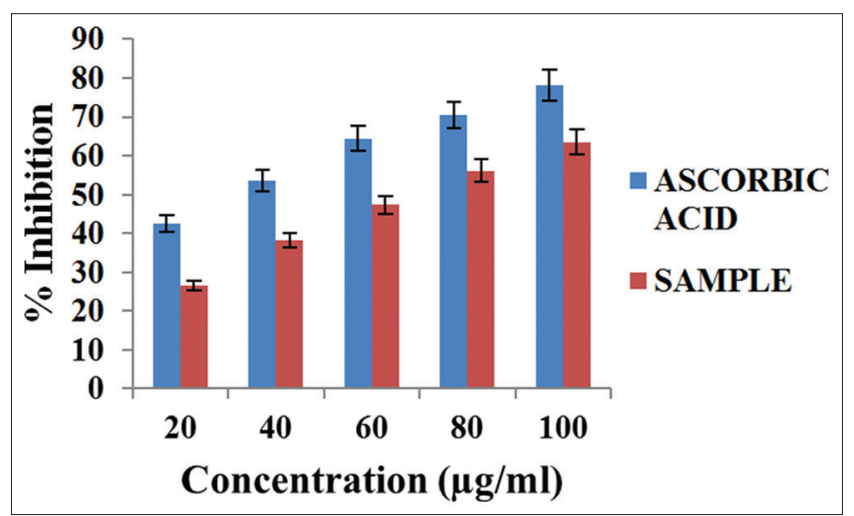

Fig. 2: Hydroxyl radical scavenging assay of Acacia catechu (L.f) Willd. leaf extract. Values are represented in mean \pm standard deviation of triplicates 
obtained at $71.04 \pm 0.48 \%$ inhibition at $100 \mu \mathrm{g} / \mathrm{ml}$ of the plant extract, whereas the standard ascorbic acid showed $85.78 \pm 0.62 \%$ inhibition at the same concentration as shown in the Fig. 3 . The $\mathrm{IC}_{50}$ value of $\mathrm{NO}^{-}$was found to be $60.74 \pm 0.37 \mu \mathrm{g} / \mathrm{ml}$. Flavonoids and phenolic compounds may be possibly involved in the $\mathrm{NO}^{-}$scavenging activity [21]. In a similar study, Bibhabasu et al. reported that the $70 \%$ methanolic heartwood extract of $A$. catechu (L.f) Willd showed promising $\mathrm{NO}^{-}$scavenging activity.

\section{So scavenging assay}

Superoxide radical is one of the strongest free radical generated within the living cells [22]. Superoxide anions are well-characterized etiological factors for the pathogenesis of various diseases [23]. The plant extract showed maximum scavenging effect for SO at $51.50 \pm 0.86 \%$ inhibition at

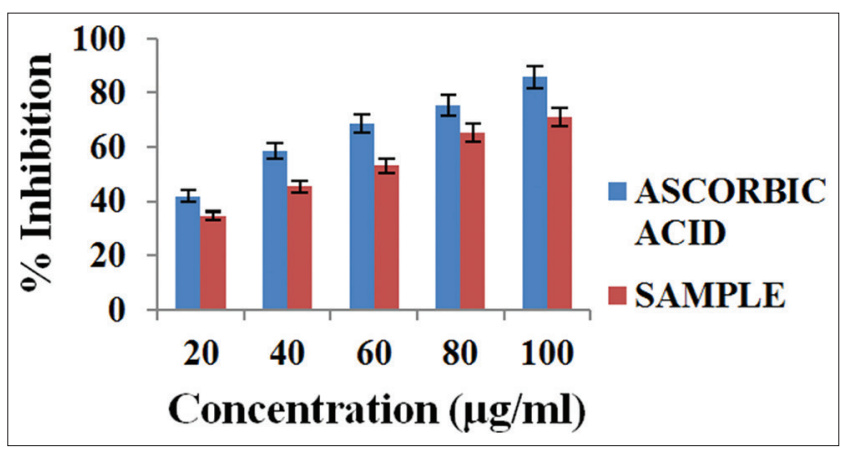

Fig. 3: Nitric oxide radical scavenging assay of Acacia catechu (L.f) Willd leaf extract. Values are represented in mean \pm standard deviation of triplicates

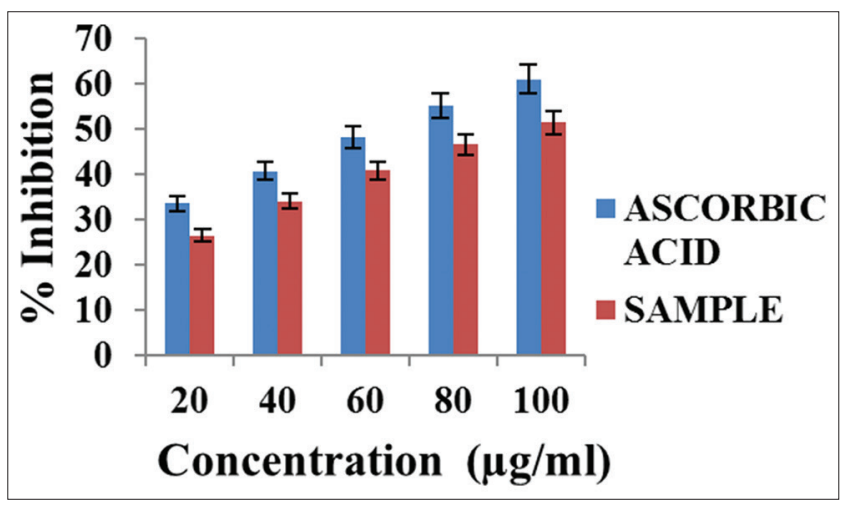

Fig. 4: Superoxide radical scavenging assay of Acacia catechu (L.f) Willd leaf extract. Values are represented in mean \pm standard deviation of triplicates

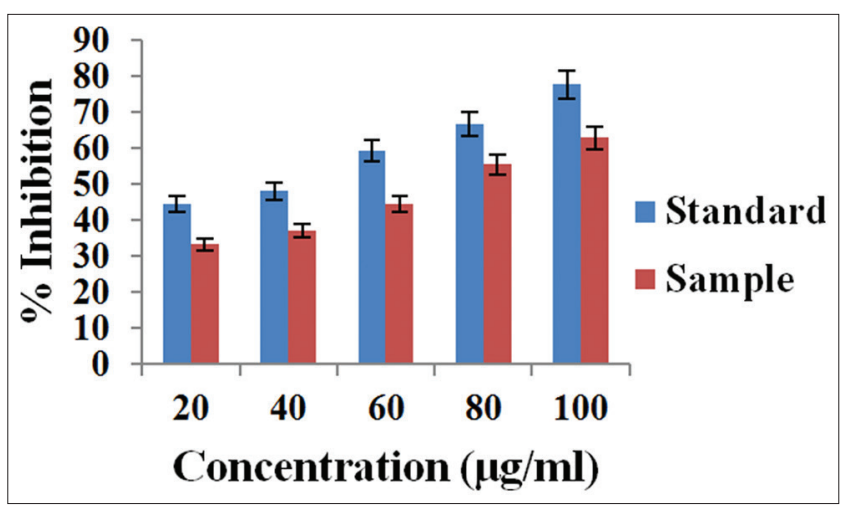

Fig. 5: $\alpha$-amylase inhibition assay of Acacia catechu (L.f) Willd leaf extract. Values are represented in mean \pm standard deviation of triplicates
$100 \mu \mathrm{g} / \mathrm{ml}$ and $61.11 \pm 1.13 \%$ was recorded for ascorbic acid as shown in the Fig. 4 . The $\mathrm{IC}_{50}$ value of SO was found to be $83.10 \pm 1.00 \mu \mathrm{g} / \mathrm{ml}$. The antioxidant property of the secondary metabolites may be attributed to the scavenging of SO. Since the A. catechu (L.f) Willd extract showed SO scavenging activity, the extract has the ability to combat various diseases through free radical scavenging activity.

\section{$\alpha$-amylase inhibition assay}

The maximum inhibitory effect for $\alpha$-amylase by the plant extract was obtained at $62.95 \%$ inhibition at $100 \mu \mathrm{g} / \mathrm{ml}$, whereas the standard maltose showed $77.77 \%$ inhibition as shown in the Fig. 5. The IC value of $\alpha$-amylase was found to be $71.17 \mu \mathrm{g} / \mathrm{ml}$. Phenolic compounds are reported to be effective human $\alpha$-amylase inhibitors [24]. Previous studies on $\alpha$-amylase inhibitors identified from medicinal herbs recommend that a number of capability inhibitors belong to flavonoid class that has features of inhibiting $\alpha$-amylase activity [25]. The presence of such inhibitors in food stuff is useful in the control of hyperglycemia as they delay carbohydrate digestion by reducing the rate of glucose absorption, thereby retard the post-prandial plasma glucose rise [26,27]

\section{CONCLUSION}

The results obtained from the presentstudy suggest that the hydroethanolic leaf extract of $A$. catechu (L.f) Willd has a significant antioxidant and antihyperglycemic activities and it can be utilized as a potential source of therapeutic agent in the management of diabetes mellitus.

\section{ACKNOWLEDGMENT}

Financial support by University Grants Commissions, in the form of Minor Research Project (No.F MRP: 6281/15 [SERO/UGC]) is acknowledged.

\section{REFERENCES}

1. Cheeseman KH, Slater TF. An introduction to free radical biochemistry. Br Med Bull 1993;49(1):481-93.

2. Young IS, Woodside JV. Antioxidants in health and disease. J Clin Pathol 2001;54(3):176-86

3. Santhoshkumar M, Anusuya N, Bhuvaneswari P. Antiulcerogenic effect of resin from shorea robusta Gaertn $\mathrm{F}$ on experimentally induced ulcer models. Int J Pharm Pharm Sci 2012;5(1):269-72.

4. Prasad DN, Rao BG, Sambasivarao E, Mallikarjunarao T, Praneeth D. Quantification of constituents and In-vitro antioxidant activity of Ficus semicordata leaves extracts. Int J Pharm Pharm Sci 2012;4(2):619-22.

5. Sudhanshu, Nidhi R, Sandhya M, Vishal, Ekta M. Antioxidant agents alternative source for malaria disease. Int J Appl Pharm 2012;4(2):14-6.

6. Betteridge DJ. What is oxidative stress? Metabolism 2000;49 2 Suppl 1:3-8.

7. Lonkar P, Dedon PC. Reactive species and DNA damage in chronic inflammation: Reconciling chemical mechanisms and biological fates. Int J Cancer 2011;128(9):1999-2009.

8. Subramanian R, Asmawi MZ, Sadikun A. In vitro alpha-glucosidase and alpha-amylase enzyme inhibitory effects of Andrographis paniculata extract and andrographolide. Acta Biochim Pol 2008;55(2):391-8.

9. Vaishali VA, Sangeeta SM, Mandar A, Kishore MP. Antioxidant and trace element potential of chyavanprash and some ayurvedic preparations. Indian J Tradit Knowl 2003;2:215-23.

10. Stohs SJ, Bagchi D. Antioxidant, anti-inflammatory, and chemoprotective properties of acacia catechu heartwood extracts. Phytother Res 2015;29(6):818-24.

11. Brand-Williams W, Cuvelier ME, Berset C. Use of free radical method to evaluate antioxidant activity. Lebensm Wiss Technol 1995;28(1):25-30.

12. Halliwell B, Gutteridge JM, Aruoma OI. The deoxyribose method: A simple 'test-tube' assay for determination of rate constants for reactions of hydroxyl radicals. Anal Biochem 1987;165(1):215-9.

13. Sreejayan N, Rao MN. Nitric oxide scavenging by curcuminoids. J Pharm Pharmacol 1997;49(1):105-7.

14. Winterbourn CC, Hawkins RE, Brian M, Carrell RW. The estimation of red cell superoxide dismutase activity. J Lab Clin Med 1975;85(2):337-41

15. Narkhede MB, Ajimire PV, Waugh E, Manoj M, Shivashanmugam AT. 
In-vitro antidiabetic activity of Caesalpinia digyna (R.) methanol root extract. Asian J Plant Sci Res 2011;1(2):101-6.

16. Liu F, Ooi VE, Chang ST. Free radical scavenging activity of mushroom polysaccharide extracts. Life Sci 1997;60(10):763-71.

17. Gutteridge JM. Reactivity of hydroxyl and hydroxyl-like radicals discriminated by release of thiobarbituric acid-reactive material from deoxy sugars, nucleosides and benzoate. Biochem J 1984;224(3):761-7.

18. Spencer JP, Jenner A, Aruoma OI, Evans PJ, Kaur H, Dexter DT, et al. Intense oxidative DNA damage promoted by L-dopa and its metabolites. Implications for neurodegenerative disease. FEBS Lett 1994;353(3):246-50.

19. Wang H, Gao X, Zhou G, Cai L, Yao WB. In-vitro and in-vivo antioxidant activity of aqueous extract from Choerospondias axillaris fruit. Food Chem 2008;106(3):888-95.

20. Reddy BS, Reddy RK, Reddy BP, Ramakrishna S, Diwan PV. Potential in-vitro antioxidant and protective effects of Soymida febrifuga on ethanol induced oxidative damage in HepG2 cells. Food Chem Toxicol 2008;46(11):3429-42.

21. Chaulya NC, Haldar PK, Mukherjee A. In-vitro free radical scavenging activity of methanol extract of rhizome of Cyperus tegetum Roxb (Cyperaceae). Int J Curr Pharm Res 2010;2(3):39-43.
22. Halliwell B, Gutteridge JM. Free Radicals in Biology and Medicine. $4^{\text {th }}$ ed. Oxford, UK: Oxford University Press; 2007.

23. Gally HF, Howdle PD, Walker BE, Webster NR. The effects of intravenous antioxidants in patients with septic shock. Free Radic Biol Med 1997;23(5):768-74.

24. Matsui T, Ueda T, Oki T, Sugita K, Terahara N, Matsumoto K. Alphaglucosidase inhibitory action of natural acylated anthocyanins 1 . Survey of natural pigments with potent inhibitory activity. J Agric Food Chem 2001;49(4):1948-51.

25. Fariba S, Gholamreza DN, Mansour M. Major flavonoids with antioxidant activity from Teucrium polium $L$. Food Chem 2009;112(4):885-8.

26. Prabhakar VK, Jaidka A, Singh R. In-vitro study on $\alpha$-amylase inhibitory activity and phytochemical screening of few Indian medicinal plant having anti-diabetic properties. Int J Sci Res Publ 2013;3(8):1-6.

27. Tarling CA, Woods K, Zhang R, Brastianos HC, Brayer GD, Andersen RJ, et al. The search for novel human pancreatic alphaamylase inhibitors: High-throughput screening of terrestrial and marine natural product extracts. Chembiochem 2008;9(3):433-8. 